\title{
PENGARUH KUALITAS LAYANAN, CITRA PERUSAHAAN DAN KEPERCAYAAN PADA LOYALITAS KONSUMEN
}

\author{
MARIS AGUNG TRIANDEWO \\ YUSTINE \\ Trisakti School of Management, JI Kyai Tapa No. 20 Jakarta Barat - Indonesia \\ maris@stietrisakti.ac.id, yus_tinee09@yahoo.com
}

\begin{abstract}
This study aims to test the factors that influence loyalty. This research was conducted by collecting 150 data as samples that would represent the population. Data collection is aimed at Bank customers in Jakarta who have used Bank services for at least 1 year. Based on the results of research that has been done there is a positive influence of trust on loyalty, there is a positive influence on service quality on trust, there is a positive influence on service quality on company image, however, there is no positive influence on service quality and company image on loyalty.
\end{abstract}

Keywords: Service quality, company image, trust, consumer loyalty

Abstrak: Penelitian ini bertujuan untuk melakukan uji faktor-faktor yang mempengaruhi loyalitas. Penelitian ini dilakukan dengan melakukan pengumpulan 150 data sebagai sampel yang akan mewakili populasi. Pengumpulan data ditujukan kepada nasabah bank di Jakarta yang telah menggunakan jasa bank minimal 1 tahun. Berdasarkan pada hasil penelitian yang telah dilakukan terdapat pengaruh positif kepercayaan pada loyalitas, terdapat pengaruh positif kualitas layanan pada kepercayaan, terdapat pengaruh positif kualitas layanan pada citra perusahaan, tetapi, tidak terdapat pengaruh positif kualitas layanan dan citra perusahaan pada loyalitas.

Kata kunci: Kualitas layanan, citra perusahaan, kepercayaan, loyalitas konsumen

\section{PENDAHULUAN}

Bank sebagai salah satu lembaga keuangan yang menawarkan jasa dalam operasionalnya merupakan suatu lembaga yang saat ini sangat diperlukan, baik untuk kelangsungan perekonomian maupun kebutuhan secara perorangan, termasuk di dalamnya adalah kebutuha untuk melakukan transaksi, menabung, meminjam dan lain sebagainya. Tidak mengherankan banyak lembaga keuangan menawarkan jasa terbaik mereka untuk memenuhi berbagai macam kebutuhan tersebut, di mana inovasi jasa sudah menjadi keharusan agar lembaga-lembaga keuangan tersebut dapat menjalankan peran terbaik mereka dalam melayani pelanggan.

Data menunjukkan bahwa peran bank sebagai salah satu lembaga keuangan menunjukkan peningkatan dari waktu ke waktu. Data dari Otoritas Jasa Keuangan (OJK) menunjukkan bahwa pada triwulan IV tahun 2018 wilayah DKI Jakarta berdasarkan pangsa wilayah memiliki penyebaran dana pihak ketiga (DPK) terbesar, yaitu sebesar $50,97 \%$ dibandingkan dengan pangsa wilayah lainnya. Data terbaru tahun 2019 DKI Jakarta masih bertahan di atas $50 \%$, yaitu $50,86 \%$, Jawa Timur $9,72 \%$, Jawa Barat $8,03 \%$, Jawa Tengah $5,12 \%$, dan Sumatera Utara $4,07 \%$. 
Dengan semakin kompetitifnya industry perbankan dan didukung oleh tingginya pertumbuhan pasar menyebabkan melimpahnya jasa di industri perbankan, sehingga persaingan berbagai perusahaan perbankan untuk merebut pangsa pasar tidak dapat dihindari. Dengan kondisi seperti itu maka kualitas layanan menjadi penting sesuai dengan Kotler \& Keller (2016), perusahaan jasa yang sangat baik menyadari bahwa loyalitas pelanggan akan diperkuat dengan adanya sikap positif karyawan. Loyalitas dianggap penting mengingat dengan tingginya loyalitas, maka makin besar kemungkinan pelanggan melakukan pembelian merek dimaksud. Sedangkan hasil dari suatu layanan dan loyalitas pelanggan dipengaruhi oleh beberapa variabel.

Menurut Kenneth (2018), loyalitas pelanggan dihasilkan dari citra positif perusahaan dalam melakukan aktifitasnya, komentar yang positif yang dilakukan oleh karyawan atau konsumennya dari mulut ke mulut atau bisa juga dari konsumen yang bahagia yang menghasilkan publisitas berkualitas. Boonlertvanich (2019) dalam penelitiannya mengungkapkan bahwa saat pelanggan melakukan pengamatan pada pengetahuan dan daya tanggap karyawan, kemudian secara terpisah melakukan evaluasi kepercayaan tersebut dari dimensi kualitas layanan lainnya, maka hal tersebut menghasilkan kepercayaan. Dengan kepercayaan akan mendorong ke loyalitas jangka panjang yang pada gilirannya memperkuat hubungan antara kedua pihak.

Bank BCA sebagai salah satu bank terbesar di Indonesia dan merupakan bank swasta terbesar memberikan berbagai layanan kepada pelanggannya, antara lain auto debit, safe deposit box, transfer, remittance, dan lain sebagainya yang tentu saja menyediakan fasilitas utama perbankan yaitu simpan pinjam. Dalam membangun kepercayaan pada konsumen, bank BCA melakukannya dengan meningkatkan produk yang berkualitas dan meningkatkan layanan yang diberikan oleh karyawan untuk mendukung dalam pemenuhan kebutuhan pelanggan. BCA juga menggunakan teknologi untuk membantu nasabah sesuai dengan yang diinginkan, antara lain dengan otomatisasi yang diaplikasikan oleh BCA dalam mengupayakan efisiensi operasional layanannya.

Dalam upaya memperkuat citra perusahaan di mata pelanggan, BCA menerapkan beberapa cara, antara lain menciptakan lingkungan kerja yang positif di antara para karyawan, memberikan penawaran produk dan layanan yang terbaik bagi stake holder yaitu nasabah, pemegang saham, dan pemangku kepentingan lainnya dalam rangka menjaga komitmen yang telah disepakati. Selain itu aspek sosial yang penting untuk menjaga hubungan baik dengan pelanggan adalah dengan pemberian beasiswa bagi lulusan SLTA ingin melanjutkan studi S1. BCA juga peduli dengan lingkungan, salah satunya dibuktikan dengan bekerjasama dengan WWF untuk pelepasan penyu dan orangutan di habitatnya.

Dalam penelitiannya, Makanyeza \& Chikazhe (2017) mengemukakan jika kualitas layanan semakin baik, maka pelanggan yang loyal akan makin banyak. Hal yang sama dengan citra organisasi yang dipandang positif atau menguntungkan, maka ada kecenderungan orang tersebut bersikap loyal kepada organisasi dan layanannya. Dalam studinya Boonlertvanich (2019) menyimpulkan bahwa terdapat pengaruh tidak langsung yang signifikan antara kualitas layanan terhadap perilaku loyalitas, melalui kepuasan dan kepercayaan, walaupun efek langsungnya tidak signifikan. Sedangkan menurut Sanjaya dan Prasatyo (2016), kualitas layanan memberikan pengaruh pada loyalitas.

Namun demikian, berdasarkan studi yang dilakukan Tabrani dan Nizam (2018), tidak terdapat hubungan antara kepercayaan dan loyalitas pelanggan. Di sisi lain, Toviyani dan Indriyanti (2017) berpendapat bahwa terdapat pengaruh kepercayaan terhadap loyalitas. Demikian juga, terdapat pengaruh positif antara kepercayaan positif dengan loyalitas (Widianingrum dan Wibisono, 2016). Di samping itu, pada variabel kualitas jasa, citra perusahaan, kepercayaan, dan loyalitas menurut Omoregie dkk (2019), terdapat penelitian yang menggambarkan hubungan langsung dan positif antara kualitas layanan dan loyalitas, tetapi penelitian lain melibatkan sejumlah variabel mediasi yang mana variabel tersebut dapat mempengaruhi hubungan di antara mereka.

\section{Kualitas Layanan}

Kualitas jasa atau layanan merupakan konstruksi beberapa dimensi dengan lima komponen, yaitu kehandalan, kepastian, tangibilitas, empati, dan responsif (Makanyeza \& Chikaze, 2017). 
Kualitas layanan adalah suatu kondisi di mana pelanggan merumuskan hasil perbandingan antara harapan suatu produk atau layanan dengan diterimanya persepsi kinerja layanan (Fauzi \& Suryani, 2018). Sedangkan menurut Stringam \& Gerdes (2019), kualitas layanan adalah seberapa jauh layanan dapat memuaskan apa yang diharapkan dan dibutuhkan oleh pelanggan.

Hubungan antara kualitas layanan dengan loyalitas dapat dijelaskan sebagai berikut. Kualitas layanan merupakan penggerak yang penting bagi loyalitas pelanggan (Omoregie at al., 2019). Pada perusahaan yang bergerak di bidang jasa, sikap karyawan yang positif akan memperkuat loyalitas pelanggan. (Kotler \& Keller, 2016). Karena itu dirumuskan hipotesa sebagai berikut:

$\mathrm{H}_{1}$ : Kualitas layanan berpengaruh positif yang signifikan terhadap loyalitas.

\section{Citra perusahaan}

Tran et al. (2015) berpendapat bahwa citra perusahaan merupakan konstruksi yang mempunyai arti "fungsional" dan "emosional". Dalam penelitiannya, Omoregie et al. (2019) mengemukakan bahwa citra perusahaan merupakan bentuk aset yang tidak berwujud pada perusahaan yang memiliki keunikan di mana mudah untuk diidentifikasi namun sukar untuk ditiru. Citra perusahaan merupakan sekumpulan arti dari pelanggan di mana pelanggan mengingat, menggambarkan, dan menghubungkan hasil pengalaman menjadi keyakinan, ingatan, perasaan serta pengetahuan (Giovannis et al. 2016). Omoregie, Addae, Coffie, Ampong and Ofori (2019) dalam penelitiannya menyatakan bahwa persepsi dari kualitas layanan mempunyai dampak yang kuat atas persepsi pelanggan mengenai citra perusahaan dan kepercayaan kepada pelanggan. Sehubungan dengan hal tersebut maka dapat ditarik beberapa hipotesa sebagai berikut.

$\mathrm{H}_{2}$ : Kualitas layanan berpengaruh positif yang signifikan terhadap citra perusahaan.

$\mathrm{H}_{3}$ : Kualitas layanan berpengaruh positif yang signifikan terhadap kepercayaan.

Citra perusahaan didifinisikan sebagai atribut institusi atau barang tidak berwujud yang secara fungsional didiskripsikan sebagai pengalaman dan pengetahuan. Dalam penelitiannya, Omoregie et al. (2019) mengemukakan bahwa citra perusahaan tidak mempengaruhi loyalitas. Namun demikian, Kaur dan Soch (2018) berpendapat bahwa citra perusahaan meningkatkan kemungkinan alternatif merek yang mana menyebabkan loyalitas pelanggan yang lebih besar dan menekan tingkat kerentanan pada kompetitifnya aktifitas pemasaran. Karena itu dapat dihipotesakan sebagai berikut:

$\mathrm{H} 4$ : Citra perusahaan berpengaruh positif yang signifikan terhadap loyalitas pada pelanggan BCA di Jakarta

\section{Kepercayaan}

Menurut Omeregei et al. (2019) kepercayaan direfleksikan oleh keinginan pelanggan agar menjadi sensitive terhadap produsen dengan mendasarkan harapan positif mengenai kualitas produk ata jasa di masa depan. Sedangkan menurut Kenneth (2018), definisi kepercayaan merupakan pelanggan yang mempercayai keampuhan dan kehandalan dari suatu merek. Boonlertvanich (2019) mengutarakan bahwa kepercayaan merupakan rasa yakin pelanggan terhadap produsen yang akan memenuhi apa yang mereka butuhkan dan tidak melakukan langkah-langkah yang tidak diduga yang akan menimbulkan sesuatu yang negatif. Dengan demikian, dengan adanya kepercayaan maka muncul harapan positif pada kualitas mutu produk atas jasa yang berupa keampuhan dan kehandalan merek.

Hubungan positif yang signifikan antara kepercayaan dan loyalitas pelanggan juga ditemukan oleh oleh Omoregei (2019). Demikian juga dengan pendapat Boonlertvanic (2019) yang mengungkapkan bahwa kepercayaan memberikan kecenderungan kepada loyalitas jangka panjang serta mempererat hubungan di antara kedua belah pihak (Boonlertvanich, 2019). Atas hubungan tersebut, dirumuskan hipotesa sebagai berikut:

$\mathrm{H}_{5}$ : Kepercayaan berpengaruh positif yang signifikan terhadap loyalitas.

\section{Loyalitas}

Menurut Kotler dan Keller (2016) loyalitas didefinisikan sebagai produk atau layanan yang dilakukan pembelian ulang dengan komitmen atau lebih digemari di masa yang akan datang walau 
dengan adanya sesuatu yang mempengaruhi suasana dan pemasaran yang berdampak pada perubahan perilaku. Definisi yang lain menyebutkan bahwa loyalitas adalah ketika pelanggan menyatakan kesediaannya untuk memberikan rekomendasi produk, kesediaan untuk berlangganan pada produsen dalam jangka panjang, serta menyukai produk dengan ekslusif (Wirtz \& Lovelock 2016). Kenneth (2018) mengatakan. Dengan demikian, loyalitas dapat diartikan sebagai suatu komitmen untuk melakukan pembelian kembali dalam jangka panjang serta memberikan rekomendasi produk perusahaan kepada rekan dan saudaranya dengan hanya satu merek.

Berikut adalah penelitian sebelumnya yang meneliti variabel yang mempengaruhi loyalitas:

Tabel 1 Penelitian Sebelumnya

\begin{tabular}{|c|c|c|c|}
\hline Referensi & Obyek & $\begin{array}{l}\text { Variabel laten } \\
\text { endogen }\end{array}$ & $\begin{array}{l}\text { Pengaruh } \\
\text { terhadap } \\
\text { variabel } \\
\text { Loyalitas }\end{array}$ \\
\hline $\begin{array}{l}\text { 1. Wu, H.-C., Cheng, C.-C., \& } \\
\text { Hussein, A. S. (2019). }\end{array}$ & Bank Islam & $\begin{array}{l}\text { Kualitas layanan } \\
\text { Kepercavaan }\end{array}$ & $\begin{array}{l}\text { Berpengaruh } \\
\text { signifikan }\end{array}$ \\
\hline $\begin{array}{l}\text { 2. Makanyeza, C., \& Chikazhe, L. } \\
(2017) \text {. }\end{array}$ & Bank & $\begin{array}{l}\text { Kualitas layanan } \\
\text { Citra perusahaan }\end{array}$ & $\begin{array}{l}\text { Berpengaruh } \\
\text { signifikan }\end{array}$ \\
\hline 3. Boonlertvanich, K. (2019). & Bank & $\begin{array}{l}\text { Kepercayaan } \\
\text { Kualitas layanan }\end{array}$ & $\begin{array}{l}\text { Berpengaruh } \\
\text { signifikan }\end{array}$ \\
\hline $\begin{array}{l}\text { 4. Fauzi, A. A., \& Suryani, T. } \\
\text { (2018). }\end{array}$ & Bank Islam & $\begin{array}{l}\text { Kepercayaan } \\
\text { Kualitas layanan }\end{array}$ & $\begin{array}{l}\text { Berpengaruh } \\
\text { signifikan }\end{array}$ \\
\hline
\end{tabular}

Dari tabel tersebut nampak bahwa kualitas layanan, citra perusahaan dan kepercayaan semuanya berpengaruh signifikan terhadap loyalitas.
Berikut ini adalah kerangka penelitian yang digunakan dalam penelitian ini:

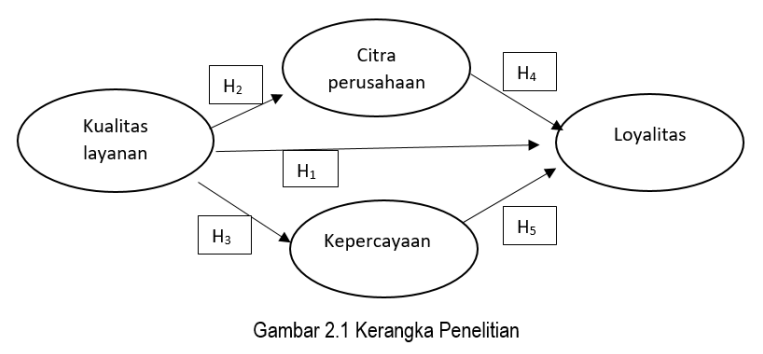

\section{METODE PENELITIAN}

Dalam penelitian ini terdapat empat variabel laten model penelitian, di mana diukur dengan beberapa indikator. Dalam upaya untuk meningkatkan validitas konten, indikator untuk konstruk ini diadaptasi dari literatur sebelumnya (Straub et al. 2004). Selanjutnya indikator-indikator dimaksud disusun ulang agar dapat mencerminkan konteks perbankan ritel. Agar pertanyaan survei menjadi "ramah responden" dan mudah dipahami, sebagai langkah awal dilakukan tinjauan kuesioner oleh profesional yang memiliki pengalaman di industri perbankan dan peneliti senior dengan keahlian pada subjek dimaksud. Pendapat para 
ahli ini dipertimbangkan pada saat melakukan revisi pertanyaan untuk meningkatkan ketepatan sasaran selama melakukan wawancara atau pengumpulan data.

Skala Likert digunakan dalam pengukuran, di mana menurut Sekaran \& Bougie (2016) skala likert adalah skala yang dirancang untuk mengetahui seberapa besar responden setuju dengan pernyataan (seperti "Saya menikmati masakan hangat") pada skala lima poin sebagai berikut: 1 = Sangat Tidak Setuju, 2 = Tidak Setuju, 3 = netral, 4 = Setuju, 5 = Sangat Setuju, dengan variabel dan indikator sebagai berikut: 1. Kualitas layanan: Karyawan bank ini memberi saya perhatian pribadi, informasi akun yang akurat diberikan oleh layanan e-banking bank saya, penyedia layanan memberikan informasi kepada saya suku bunga yang tepat atau biaya layanan atau penawaran khusus, penyedia layanan dapat diakses melalui berbagai cara (online, telepon, secara langsung, ATM); 2. Citra perusahaan: Bank saya dapat dipercaya baik apa yang dikatakan maupun dilakukan, bank saya stabil dan mapan, bank saya mempunyai kontribusi sosial bagi masyarakat, Bank saya mempunyai citra positif di mata para nasabahnya, bank saya inovatif dan mempunyai wawasan ke depan; 3. Kepercayaan: Dengan pertimbangan rekam jejak bank saya, saya mempunyai alasan kuat untuk mempercayai kompetensi mereka, dengan pertimbangan rekam jejak bank saya, saya tidak punya keraguan untuk bertindak berdasarkan saran mereka, Bank saya menunjukkan sikap yang hangat dan peduli terhadap saya, jika saya berbagi masalah dengan bank saya, saya merasa mereka akan merespons dengan penuh perhatian; 4. Loyalitas: Saya berniat untuk menggunakan layanan bank ini lagi di kemudian hari, ada kemungkinan bahwa saya akan menggunakan lagi bank ini kedepannya, saya akan mengatakan sesuatu yang positif tentang bank ini kepada orang lain, saya akan merekomendasikan bank ini kepada orang lain yang meminta saran saya.

Penelitian ini menggunakan data primer sebagai sumber data, yang merupakan data yang dikumpulkan secara langsung untuk dilakukan analisa dalam upaya menemukan solusi untuk masalah yang diteliti dengan menggunakan kuesioner (Sekaran \& Bougie, 2016). Pengambilan sampel dilakukan menggunakan metode non-probability sampling, sebagaimana dikemukakan Sekaran dan Bougie (2016) "dalam rancangan pengambilan sampel yang nonprobabilitas, unsur-unsur dalam populasi tidak memiliki probabilitas yang melekat pada pemilihannya sebagai subjek sampel."

Populasi dari penelitian ini adalah pengguna bank BCA di Jakarta, sehingga responden untuk sampel penelitian adalah pengguna di beberapa bank BCA terpilih di Jakarta dengan kriteria sebagai berikut:

1. Umur minimal adakah 17 tahun (BCA mensyaratkan pembukaan rekening dengan KTP, SIM atau PASPOR).

2. Telah menjadi nasabah simpanan pada Bank BCA paling sedikit 1 tahun, mengingat hal itu dapat diasumsikan sebagai nasabah loyal yang sudah melakukan atau berpengalaman melakukan transaksi perbankan (Trisusanti, 2017).

3. Nasabah yang sedang menunggu antrian untuk dilayani ditanya apakah mereka adalah nasabah bank itu. Bagi yang menjawab setuju dan bersedia untuk berpartisipasi diberikan kuesioner untuk diisi (Omoregie dkk, 2019).

Menurut Hair et al (2017) jumlah minimum sampel yang sebaiknya dipakai adalah 10 kali dari jumlah seluruh panah variable laten pada model jalur atau 10 kali dari jumlah indikator. Dalam analisis multivariate, paling sedikit jumlah anggota sampel adalah10 kali dari jumlah variabel yang di teliti (Sugiono, 2017). Dalam penelitian ini sampel yang didapatkan 
berjumlah 150 responden, sehingga dengan jumlah panah variabel laten sebanyak lima atau variabel yang diteliti sebanyak empat, maka jumlah minimum sebanyak 50 atau 40 , yang artinya syarat minimal jumlah sampel terpenuhi karena masih di bawah 150 responden.

SEM digunakan dalam melakukan analisis data yang telah terkumpul. SEM merupakan suatu teknik multivariate di mana aspek analisis faktor dan regresi digabungkan, sehingga peneliti dapat mengukur hubungan antara variabel laten dan variabel yang diukur secara simultan (Hair et al. 2017). Adapun software yang digunakan adalah PLS 3.0.
HASIL

Sebagaimana disajikan pada tabel 2 di bawah, secara keseluruhan jumlah mayoritas responden adalah perempuan, yaitu 91 orang sedangkan laki laki sebanyak 59 orang, di mana usia terbanyak adalah antara 21 - 30 tahun. Dari sisi profesi, terbanyak adalah sebagai karyawan $50 \%$, diikuti pelajar sebesar $26.7 \%$ dan terendah adalah wirausaha sebesar $11.3 \%$ atau hanya 17 orang.

Tabel 2 Data Deskriptif Responden

\begin{tabular}{|c|c|c|c|c|c|}
\hline \multicolumn{2}{|c|}{ Items } & Frequency & Percent & Valid Percent & $\begin{array}{c}\text { Cumulative } \\
\text { Percent }\end{array}$ \\
\hline \multirow[t]{3}{*}{ Jenis Kelamin } & Laki-laki & 59 & 39.3 & 39.3 & 39.3 \\
\hline & Perempuan & 91 & 60.7 & 60.7 & 100.0 \\
\hline & Total & 150 & 100.0 & 100.0 & \\
\hline \multirow[t]{5}{*}{ Usia } & $17-20$ & 14 & 9.3 & 9.3 & 9.3 \\
\hline & $21-30$ & 96 & 64.0 & 64.0 & 73.3 \\
\hline & $31-40$ & 31 & 20.7 & 20.7 & 94.0 \\
\hline & $41-50$ & 9 & 6.0 & 6.0 & 100.0 \\
\hline & Total & 150 & 100.0 & 100.0 & \\
\hline \multirow[t]{5}{*}{ Profesi } & Pelajar & 40 & 26.7 & 26.7 & 26.7 \\
\hline & Karyawan & 75 & 50.0 & 50.0 & 76. \\
\hline & $\begin{array}{l}\text { lbu rumah } \\
\text { tangga }\end{array}$ & 18 & 12.0 & 12.0 & 88.7 \\
\hline & Wirausaha & 17 & 11.3 & 11.3 & 100.0 \\
\hline & Total & 150 & 100.0 & 100.0 & \\
\hline
\end{tabular}

Untuk mengukur validitas konvergen (Hair et al, 2017), maka penilaian dalam model ini menggunakan konsistensi internal, indikator relibilitas, dan rata-rata variance extracted (AVE) 


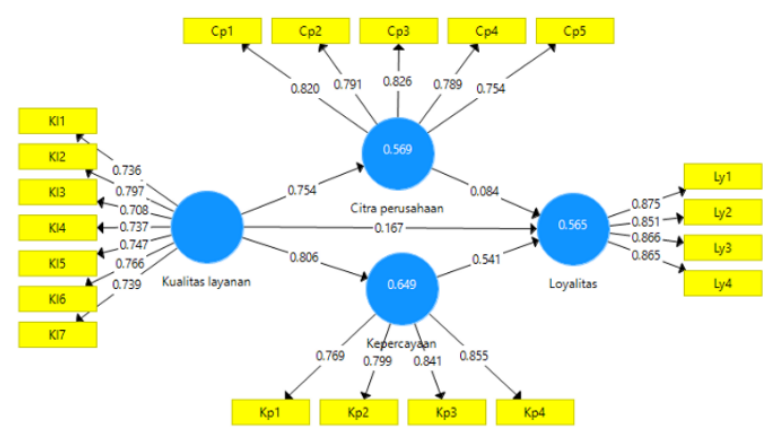

Gambar 1 Outter Model

Tabel 3 Konsistensi Reliabilitas

\begin{tabular}{lll}
\hline Variabel & $\begin{array}{l}\text { Composite } \\
\text { reliability }\end{array}$ & $\begin{array}{l}\text { Cronbach } \\
\text { Alpha }\end{array}$ \\
\hline Kualitas layanan & 0.899 & 0.868 \\
Citra perusahaan & 0.896 & 0.855 \\
Kepercayaan & 0.889 & 0.834 \\
Loyalitas & 0.922 & 0.887 \\
\hline
\end{tabular}

Dari tabel perhitungan di atas menunjukkan reliabilitas yang cukup baik karena memenuhi kriteria batas indikator yaitu antara 0 dan1 di mana semakin mendekati 1 maka reliabilitas semakin baik, yaitu composite reliability kualitas layanan sebesar 0.899 , citra perusahaan sebesar 0.896, kepercayaan sebesar 0.889 , dan loyalitas sebesar 0.922 . Di samping itu Cronbach alpha memenuhi kriteria yang diinginkan yaitu antara 0,70 dan 0,90 (Hair et al, 2017), yaitu kualitas layanan sebesar 0.868, citra perusahaan sebesar 0.855 , kepercayaan sebesar 0.834 , dan loyalitas sebesar 0.887 .

Tabel 4 Validitas Konvergen

\begin{tabular}{|c|c|c|c|}
\hline Variabel & Indikator & Factor loading & AVE \\
\hline \multirow[b]{7}{*}{ Kualitas layanan } & $\mathrm{KI} 1$ & 0.736 & \multirow[b]{7}{*}{0.559} \\
\hline & $\mathrm{Kl} 2$ & 0.797 & \\
\hline & $\mathrm{KI} 3$ & 0.708 & \\
\hline & $\mathrm{KI} 4$ & 0.737 & \\
\hline & $\mathrm{KI} 5$ & 0.747 & \\
\hline & $\mathrm{KI} 6$ & 0.766 & \\
\hline & $\mathrm{KI} 7$ & 0.739 & \\
\hline \multirow[b]{3}{*}{ Citra perusahaan } & Cp1 & 0.82 & \multirow[b]{3}{*}{0.634} \\
\hline & Cp2 & 0.791 & \\
\hline & Cp3 & 0.826 & \\
\hline
\end{tabular}




\begin{tabular}{|l|l|l|l|} 
& Cp4 & 0.789 & \\
\cline { 2 - 3 } & Cp5 & 0.754 & \\
\hline \multirow{5}{*}{ Kepercayaan } & Kp1 & 0.769 & \\
\cline { 2 - 4 } & Kp2 & 0.799 & 0.667 \\
\cline { 2 - 4 } & Kp3 & 0.841 & \\
\cline { 2 - 4 } Loyalitas & Kp4 & 0.855 & \multirow{2}{*}{0.747} \\
\hline
\end{tabular}

Tabel di atas menunjukkan bahwa kualitas layanan mempunyai loading terendah dengan nilai 0.708 dan tertinggi dengan nilai 0.797, citra perusahaan dengan loading terendah sebesar 0.754 dan tertinggi sebesar 0.826 , kepercayaan dengan loading terendah dengan nilai 0.769 dan tertinggi sebesar 0.855 , dan loyalitas memiliki loading terendah sebesar 0.851 dan tertinggi sebesar 0.875 . Secara keseluruhan nilai terendah yang didapat adalah 0.708 sehingga memenuhi kriteria minimal sesuai ketentuan. Demikian juga dengan AVE di mana semua variable telah memenuhi batas minimal sebesar $>0,5$ dengan rincian kualitas layanan dengan nilai 0.559 , citra perusahaan dengan nilai 0.634 , kepercayaan dengan nilai 0.667 , serta loyalitas dengan nilai 0.747 (Hair et al. 2017).

Tabel 5 Validitas Diskriminan

\begin{tabular}{lllll}
\hline Indikator & $\begin{array}{l}\text { Kualitas } \\
\text { layanan }\end{array}$ & $\begin{array}{l}\text { Citra } \\
\text { perusahaan }\end{array}$ & Kepercayaan & Loyalitas \\
\hline KI1 & 0,736 & 0,579 & 0,658 & 0,545 \\
KI2 & 0,797 & 0,547 & 0,624 & 0,518 \\
KI3 & 0,708 & 0,52 & 0,578 & 0,513 \\
KI4 & 0,737 & 0,562 & 0,551 & 0,457 \\
KI5 & 0,747 & 0,579 & 0,584 & 0,475 \\
KI6 & 0,766 & 0,607 & 0,607 & 0,512 \\
KI7 & 0,739 & 0,548 & 0,606 & 0,456 \\
Cp1 & 0,646 & 0,82 & 0,679 & 0,558 \\
Cp2 & 0,57 & 0,791 & 0,57 & 0,498 \\
Cp3 & 0,617 & 0,826 & 0,633 & 0,462 \\
Cp4 & 0,622 & 0,789 & 0,608 & 0,476 \\
Cp5 & 0,542 & 0,754 & 0,619 & 0,52 \\
Kp1 & 0,633 & 0,649 & 0,769 & 0,641 \\
Kp2 & 0,514 & 0,587 & 0,799 & 0,501 \\
Kp3 & 0,758 & 0,637 & 0,841 & 0,637 \\
Kp4 & 0,691 & 0,675 & 0,855 & 0,619 \\
Ly1 & 0,631 & 0,614 & 0,686 & 0,875 \\
Ly2 & 0,565 & 0,531 & 0,594 & 0,851 \\
\hline
\end{tabular}




\begin{tabular}{lllll}
\hline Ly3 & 0,591 & 0,524 & 0,649 & 0,866 \\
Ly4 & 0,507 & 0,51 & 0,625 & 0,865 \\
\hline
\end{tabular}

Indikator-indikator konstrak lebih besar nilainya daripada konstrak yang lainnya, maka konstrak laten lebih baik dibandingkan dengan konstruk lainnya, sebagai contoh indicator Ly4 mempunyai nilai 0,865 di mana lebih besar dari
$0.507,0.51$, dan 0.625. Demikian juga dengan indikator-indikator lainnya.

Evaluasi R2, Q2, dan uji t digunakan untuk mengetahui seberapa besar daya prediksi variable endogen (Hair et al. 2017).

Tabel 6 Coefficient of Determinant (R2)

\begin{tabular}{ll}
\hline Variabel & R Square (R2) \\
\hline Citra perusahaan & 0.569 \\
Kepercayaan & 0.649 \\
Loyalitas & 0.565 \\
\hline
\end{tabular}

Dari tabel di atas terlihat bahwa lebih dari $50 \%$ semua variabel tersebut dapat dijelaskan oleh variabel terkait masing-masing dan kurang dari $50 \%$ oleh variabel lain yang tidak diteliti, sehingga dapat disimpulkan bahwa dengan koefisien determinasi yang lebih besar dari 0.5 menunjukkan validitas yang baik (Hair et al. 2017).

Tabel 7 Test Relevansi

\begin{tabular}{ll}
\hline Variabel & $\mathbf{Q}^{\mathbf{2}} \quad(=1-$ \\
Citra perusahaan & 0.336 \\
Kepercayaan & 0.398 \\
Loyalitas & 0.389 \\
\hline
\end{tabular}

Nilai di atas 0 , maka terdapat relevansi pada variabel endogen (Hair et al. 2017) yaitu citra perusahaan dengan nilai 0,336 , kepercayaan dengan nilai 0,398 serta loyalitas dengan nilai 0,389 .

Tabel 8 Uni t

\begin{tabular}{|c|c|c|c|c|c|c|}
\hline Variabel & $\begin{array}{c}\text { Original } \\
\text { Sample } \\
(0)\end{array}$ & $\begin{array}{c}\text { Sample } \\
\text { Mean (M) }\end{array}$ & $\begin{array}{l}\text { Standard } \\
\text { Deviation } \\
\text { (STDEV) }\end{array}$ & $\begin{array}{l}\text { T Statistics } \\
\text { (|O/STDEV } \mid)\end{array}$ & $\begin{array}{c}P \\
\text { Values }\end{array}$ & Hasil \\
\hline $\begin{array}{l}\text { Kualitas layanan -> Loyalitas } \\
\text { (H1) }\end{array}$ & 0.167 & 0.167 & 0.099 & 1.684 & 0.093 & Ditolak \\
\hline $\begin{array}{l}\text { Kualitas layanan } \quad \rightarrow \quad \text { Citra } \\
\text { perusahaan }(\mathrm{H} 2)\end{array}$ & 0.754 & 0.754 & 0.039 & 19.464 & 0 & Diterima \\
\hline $\begin{array}{ll}\text { Kualitas layanan } & \rightarrow \\
\text { Kepercayaan }(\mathrm{H} 3) & \end{array}$ & 0.806 & 0.805 & 0.035 & 22.871 & 0 & Diterima \\
\hline
\end{tabular}




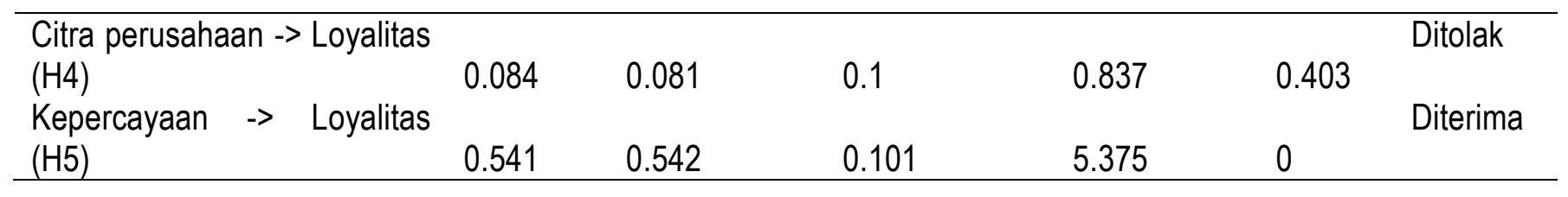

Dari uji $t$ tersebut di atas, dapat disimpulkan tidak terdapat pengaruh positif yang signifikan dari kualitas layanan terhadap loyalitas karena nilai uji t lebih kecil dibanding $T$ tabel $(1,684<1,96)$ sehingga $H_{1}$ ditolak. Sementara pada kualitas layanan terhadap citra perusahaan terdapat pengaruh positif yang signifikan ditandai dengan nilai uji t lebih besar dibanding $\mathrm{T}$ tabel $(19,464>1,96)$, sehingga $\mathrm{H}_{2}$ diterima. Pada variabel kualitas layanan terhadap citra perusahaan terdapat pengaruh positif yang signifikan ditunjukkan dengan nilai uji t lebih besar dibanding $T$ tabel $(22,871>1,96)$, sehingga $\mathrm{H}_{3}$ diterima. Sementara itu pada variabel citra perusahaan terhadap loyalitas, tidak terdapat pengaruh positif yang signifikan ditandai dengan nilai uji t lebih kecil dibanding $T$ tabel $(0.837<1,96)$, sehingga $\mathrm{H}_{4}$ ditolak. Dan yang terakhir, pada variabel kepercayaan terhadap loyalitas, terdapat pengaruh positif yang signifikan ditandai dengan nilai uji t lebih besar dibanding $T$ tabel $(5,375>1,96)$, sehingga $\mathrm{H}_{5}$ diterima.

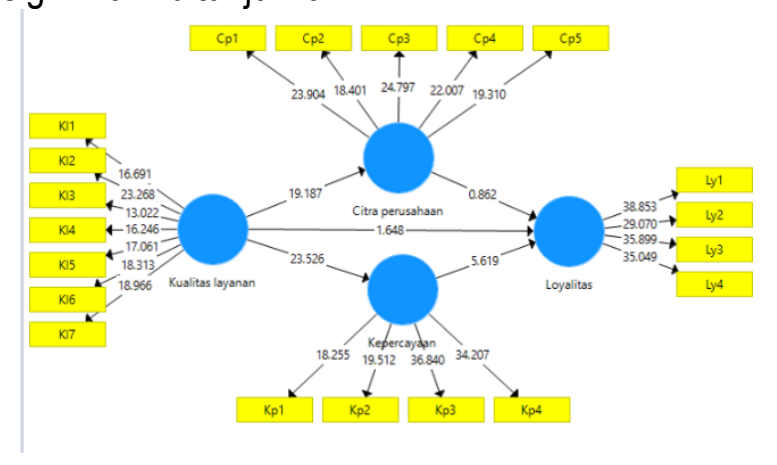

Gambar 2 Inner Model

\section{PENUTUP}

Dari hasil penelitian diperoleh kesimpulan sebagai berikut:

1. Tidak terdapat pengaruh positif kualitas layanan terhadap loyalitas pada pelanggan BCA di Jakarta, sehingga tidak sesuai dengan penelitian Makanyeza \& Chikazhe (2017), menyiratkan bahwa semakin baik kualitas layanan tidak membuat pelanggan semakin loyal

2. Terdapat pengaruh positif kualitas layanan terhadap citra perusahaan pada pelanggan BCA di Jakarta, sesuai dengan penelitian Makanyeza \& Chikazhe (2017), menyiratkan bahwa semakin baik kualitas layanan, semakin banyak pelanggan yang loyal. Tidak sesuai dengan penelitian Omoregie dkk (2019) di mana citra perusahaan tidak mempengaruhi loyalitas.

3. Terdapat pengaruh positif kualitas layanan terhadap kepercayaan pada pelanggan BCA di Jakarta, sehingga sesuai dengan penelitian Omoregie dkk (2019).

4. Tidak terdapat pengaruh positif citra perusahaan terhadap loyalitas pada pelanggan BCA di Jakarta, di mana hal ini sesuai dengan penelitian Omoregie dkk (2019) bahwa citra perusahaan tidak mempengaruhi loyalitas. Namun tidak sesuai dengan penelitian Kaur \& Soch (2018) yang menyatakan bahwa citra perusahaan yang diinginkan akan 
meningkatkan kemungkinan pilihan merek di mana hal itu menyebabkan loyalitas konsumen bertambah serta mengurangi kerentanan terhadap tindakan pemasaran yang kompetitif.

5. Terdapat pengaruh positif kepercayaan terhadap loyalitas pada pelanggan BCA di Jakarta, di mana hal ini tidak sesuai dengan penelitian Tabrani \& Nizam (2018) yang menyatakan bahwa tidak ada efek langsung kepercayaan pada loyalitas pelanggan. Namun penelitian ini sesuai dengan penelitian Omoregie dkk (2019) di mana kepercayaan memiliki hubungan signifikan positif dengan loyalitas pelanggan.

Hasil dari penelitian ini membawa implikasi, baik teoritis maupun manajerial. Implikasi teoritis diperoleh dari dua hipotesa yang ditolak, yaitu kualitas layanan pada loyalitas dan citra perusahaan pada loyalitas. Pada penelitianpenelitian sebelumnya, baik kualitas layanan maupun citra perusahaan menunjukkan pengaruh postif yang signifikan pada loyalitas. Namun pada penelitian ini, hal yang sebaliknya yang terjadi, keduanya tidak menunjukkan pengaruh yang signifikan dan positif pada loyalitas. Alasan yang paling memungkinkan adalah obyek responden yang berbeda, di mana pada penelitian ini semua responden adalah penduduk di Indonesia yang mempunyai budaya dan latar belakan sosiologis yang berbeda dengan penelitian-penelian sebelumnya. Demikian juga pemahaman dalam membaca kuesionar yang tidak sesuai dengan kondisi sebenernya yang diharapkan dalam mengisi kuesioner sehingga menimbulkan perbedaan persepsi dalam mencerna pertanyaan. Atau bisa jadi memang penduduk di Indonesia tidak terlalu mementingkan kualitas layanan dan citra perusahaan dalam pembelian produk sehingga hal tersebut tidak akan membangkitkan perasaan loyalitas terhadap produk yang dibelinya. Dengan demikian, hal tersebut dapat menjadikan kontribusi baru pada literatur yang ada saat ini.

Implikasi manajerial dikemukakan dengan harapan dapat memberikan saran atau masukan kepada pengelola/manajemen. Masukan diutamakan pada hal-hal yang hipotesanya ditolak, yaitu kualitas layanan dan citra perusahaan. Maka dari itu perlu dilakukan upaya-upaya agar kualitas layanan dan citra perusahaan meningkat. Misalnya menambah pelatihan bagi pegawainya khususnya pegawai yang langsung berinteraksi dengan pelanggan (front office) sehingga lebih memberikan sentuhan secara pribadi pada pelanggan, peningkatan layanan e-banking dengan penambahan dan penyempurnaan menu atau pilihan transaksi, dan jika diperlukan dapat menambah jam operasional pelayanan misalnya di hari Sabtu di mana hal tersebut akan semakin menambah pelanggan lebih nyaman dalam bertransaksi. Sedangkan untuk citra perusahaan, perusahaan dapat meningkatkan citra nya dengan beberapa cara, antara lain dengan meningkatkan kegiatan corporate social responsibility namun yang bener-bener tepat sasaran dalam alokasinya, sehingga nama pesusahaan menjadi lebih dikenal masyarakat yang pada gilirannya akan meningkatkan citra perusahaan.

Dalam penelitian ini terdapat keterbatasan, yaitu:

1. Penelitian ini dilaksanakan dalam waktu yang sangat singkat, sehingga pengumpulan data dan pengolahannya terkendalan dengan singkatnya waktu. Di samping itu biaya yang timbul juga cukup banyak. Dengan keterbatasan kedua hal tersebut, maka pengambilan sampel masih kurang sempurna karena hanya mewakili beberapa bagian saja, mengingat banyaknya jumlah BCA yang beroperasi di Jakarta.

2. Jumlah sampel sebanyak 150 yang hanya merupakan sebagian kecil dari populasi pengguna BCA di Jakarta.

Untuk penelitian selanjutnya penggunaan sampel disarankan lebih banyak lagi sehingga dapat lebih mewakili populasi. Demikian juga dengan penggunaan variabel independen lainnya yang berlandaskan pada teori dan penelitian sebelumnya. 


\section{REFERENCES:}

Abu Amar Fauzi, Tatik Suryani, 2018. Measuring the effects of service quality by using CARTER model towards customer satisfaction, trust and loyalty in Indonesian Islamic banking.

Betsy Stringam, John Gerdes, 2019. Service gap in hotel website load performance. International Hospitality Review.

Boonlertvanich, K. (2019). Service quality, satisfaction, trust, and loyalty: the moderating role of main-bank and wealth status. International Journal of Bank Marketing, 37(1), 278-302.

Clow, Kenneth E. and Donald Baack (2018). Integrated Advertising, Promotion, and Marketing Communications. 8th Edition.USA: Pearson.

Giovanis, A, Athanasopoulou, P., and Tsoukatos, E. (2016). Corporate Image and Switching Barriers in The Service Evaluation Process: Evidence From The Mobile Telecommuncatios industry. Euromed Journal of Business.

Hair, Joseph F.,G. Tomas M. Hult., Christian M. Ringle., and Marko Sarstedt. 2017. A Primer on Partial Least Squares Structural Equation Modelling (PLS-SEM). 2e Edition USA: Sage.

Harsandaldeep Kaur, Harmeen Soch 2018. Satisfaction, Trust and Loyalty: Investigating the Mediating Effects of Commitment, Switching Costs and Corporate Image. Journal of Asia Business Studies.

Hung-Che Wu, Ching-Chan Cheng, Ananda Sabil Hussein, 2019 "What drives experiential loyalty towards the banks? The case of Islamic banks in Indonesia.

Kotler, Philip and Kevin Lane Keller 2016. Marketing Management. 15th Edition.USA: Pearson.

Lovelock, Christoper dan Wirtz Jochen 2016. Service Marketing: People, Technology and Strategy. 8th Edition.USA: Pearson Prentice Hall.

Makanyeza, C,. \& Chikazhe, L. 2017. Mediators of the relationship between service quality and customer loyalty. International Journal of Bank Marketing, 35(3), 540-556. doi:10.1108/ijbm-11-2016-0164.

Omoregie, Addae, Coffie, Ampong and Ofori, 2019. "Factors influencing consumer loyalty: evidence from the Ghanaian retail banking industry", International Journal of Bank Marketing, https://doi.org/10.1108/ IJBM04-2018-0099

Sanjaya, Untung dan Klemens Wedanaji Prasatyo 2016. Pengaruh Kualitas Layanan, Harga dan Kepuasan Pelanggan Terhadap Loyalitas Penonton untuk Menonton Film (2016). Jurnal Bisnis dan Akuntansi, 18(1).

Sekaran, Uma and Roger Bougie 2016. Research Methods for Business: A Skill Building Approach. 7th Edition, United Kingdom: John Wiley and Sons Ltd.

Tabrani, M., Amin, M., \& Nizam, A. 2018. Trust, commitment, customer intimacy and customer loyalty in Islamic banking relationships. International Journal of Bank Marketing, 36(5), 823-848. doi:10.1108/ijbm-032017-0054.

Toviani, Tania dan Irma Satya Indriyanti 2017. Pengaruh Brand Evaluation, Trust, Satisfaction, Brand Relationship, Brand Effect, dan Brand Image Terhadap Brand Loyalty Sabun Mandi Antiseptik. Jurnal Bisnis dan Akuntansi, 19(1a-4).

Tran, M. A., Nguyen, B., Melewar, T.C., and Bodoh, J. 2015. Exploring The Corporate Image Formation Process. Qualitative Market Research: An International Journal.

Widianingrum, Syarifah Putrid dan Wibisono Soediono 2016. The effect of Trust, Communication and Satisfaction on Loyalty of The Car Insurance Customer. Jurnal Bisnis dan Akuntansi, 18(1). 